\title{
Monastic Economy and Policy
}

\section{INTRODUCTION}

To date, no in-depth studies of monastic economy in Tibetan areas have been done. Writing in 1961, Miller questions the validity of the depiction of Tibetan monastic economies in which the monastery is portrayed as a centralized and corporate institution, but adds that "[we] need desperately a study of the Tibetan and monastic economies before firm conclusions can be drawn." Dreyfus also notes that "it is quite remarkable that there is still no systematic study of the administrative and financial structures and practices of monasteries, institutions so central to traditional Tibetan culture."' One of the most important reasons that a thorough study has not been conducted to date is that sources indispensable for quantitative research are currently not available to researchers.

A study of the place of a monastery and its relation to the broader society should be interested less with the mere factual data of the different administrative systems of Tibetan monasteries and their monastic economies, and more with how these were conceived of by Tibetan monastic authors, who held a certain level of moral authority. ${ }^{3}$ Phrased differently, according to Durkheimian theory, there are two circuits of social life: "one, the everyday, is the short-term, individuated and materialistic; the other, the social, is long-term, collective and idealized, even spiritual."4 To the minds of many, the topic of economics falls under the first circuit, whereas most societies attempt to subordinate this to their own cultural or religious conditions, i.e., the second circuit. This chapter addresses the circuit that consists of the long-term and the idealized, which in this context is the monastic economic policies and the monastic attitudes to economic matters as represented by the monastic guidelines. 
Attitudes change when circumstances change, such that changing attitudes-as detected in works that contain allusions to monastic economic behavior-have the potential to inform us about certain economic developments among the monasteries. According to Sayer, "economic phenomena both depend on and influence moral/ethical sentiments, norms and behaviors and have ethical implications."5 When considering these mutual influences, one can see how attitudes regarding economic behavior may inform us about actual economic behavior, both on a macro- and a micro-level.

With an understanding of the conceptual and moral framework of monastic economic policies, one can better comprehend the socioeconomic interrelations between lay and monastic societies. Shakya notes in this regard:

The Tibetan masses may have resented the wealth and privilege of the lay aristocracy, but the question of the economic power enjoyed by the religious institutions was viewed differently. For non-Tibetans, the economic power of the monastery was simply exploitation and the position of the lamas and the monks parasitic. But for the Tibetans such thoughts were irrelevant: they were willing to accept the special position enjoyed by the religious institutions and in fact much of the wealth of the monasteries was accumulated over centuries from voluntary contributions from the masses. ${ }^{6}$

How then was this privileged position maintained by the monastery and why did laypeople apparently accept and support these religious institutions that held such sway over their lives?

There are many misconceptions about the economic systems of monastic institutions. Particularly in studies that deal with the current state of monasteries in Tibetan areas, ahistorical notions abound. In describing the processes through which contemporary monasteries try to find "alternative" ways of managing financial matters, such as tourism, state funding, or shopkeeping, a comment regularly made is that in the olden days monks did not have to resort to such methods. In one such study the author writes that unlike in "pre-revolutionary times when the monastery supported its clergy through a feudal system of land rents, the new generation of monks had to be self-supporting." Such statements indicate a lack of appreciation for the earlier monastic economic systems.

It is certainly not true that historically monasteries (always) supported monks' livelihoods. We know this from oral accounts of monks who lived in various Tibetan areas before the 1950s, but this is also evidenced by both very early and rather late Tibetan texts. Dreyfus further confirms this by remarking that in Tibet the large monasteries did not provide for their monks, except at assemblies during which tea was served, although this was not enough to live on. ${ }^{8}$ Only the very determined, the well connected, and the wealthier studying monks would be able to bring their studies to a successful end and not have substantial financial difficulties. This was at least the case at the Three Great Seats. Local monasteries generally tended to be easier places to live in, not least because monks often had 
their relatives nearby who could support them. ${ }^{9}$ One such smaller monastery was the Pabongka hermitage during the late eighteenth or early nineteenth century; according to its guidelines: "During assemblies, generally speaking, every day all are provided with seven rounds of tea and/or soup, without fail." ${ }^{\circ}$ This may mean that monks were relatively well fed there, although the authorities did not necessarily cover other expenses. Another problem with the contention cited above is that not all monasteries upheld a "feudal system of land rents," as there were many that did not have land to rent out.

It is exactly this diversity in monastic economic systems and in Tibetan monasteries in general that makes it hard, and perhaps impossible, to present the economics of the pre-modern Tibetan monastery in a comprehensive manner. However, it is certainly essential to make a distinction between local and central monasteries. The local ones were often small, whereas the central monasteries were training centers attracting monks from affiliated local monasteries. The large central monasteries were often at the heart of a far-reaching network of smaller, local monasteries. ${ }^{11}$ The differences with regard to the economic circumstances were not necessarily determined only by the number of inhabitants, but were also dependent on the location, the political circumstances, and the "purpose" of the monastery. A monastery consisting of monks hailing from the vicinity would often have a strong ritual function in the local community. The relative prosperity of the laypeople living in the direct surroundings would have an impact on the economic situation of the monastery, regardless of whether the monasteries owned land, or whether they were involved in trade and other financial transactions.

While monks regularly lived at a subsistence level, there was a tendency for the wealthier monasteries to hoard their resources. ${ }^{12}$ As alluded to in the previous chapter, there was a rather strict division between the monastic corporation and the individual monks. This divide was particularly pronounced when it came to economic matters. This was also noted, but not elaborated on, by Stein:

We must accordingly reckon with a certain difference between the ecclesiastic community and the individual prelate. The former tended to hoard and accumulate wealth and political power. The latter was often a factor in their circulation, in both a centripetal and centrifugal sense. ${ }^{13}$

This chapter, then, attempts to explain the rules and attitudes at the monastic institutions with regard to financial and economic matters, such as commerce, property, inheritance, investment, and the redistribution of wealth. ${ }^{14}$

\section{INDIVIDUAL ECONOMIC SPHERES VS. THE SANGHA'S} ECONOMIC SPHERE

Dungkar Lopzang Trinlé, in describing the developments of Buddhist monastic economy, gives a periodization of its development, starting in India and ending 
in Tibet. On the monastic economy in India he notes that the monastery had four types of general income.

1. Offerings made to the body, speech and mind, ${ }^{15}$ used to repair the temples and so forth

2. That which fell under offerings received for teaching the dharma given to those who taught the dharma

3. That which was not to be divided up, but intended as the general possession of the Sangha

4. That which was to be divided equally among all, regardless of the amount.

These four types of wealth then were not to be moved from one to the other. Furthermore, to sell the general assets to provide loans, collect interest, assume sureties, and the like were allowed for the sake of the Sangha in general, but not for the individual monk. ${ }^{16}$

The above-outlined rules, which have their origin in the normative Vinaya, indicate that monks were already involved in property law and the like early on in India. ${ }^{17}$ While this fourfold schema cannot have been strictly enforced throughout the Buddhist monastic world, it was not just in India where a-theoreticaldistinction between different types of property, income, and offerings was upheld..$^{18}$ In Tibet, the monastic guidelines demonstrate that the most strictly adhered to division was that between the individual and the Sangha: "An individual should not come to own the general possessions of the Sangha and use them without this being necessary. Not even the smallest piece of grass or wood should be taken and the general welfare should be taken to heart as much as possible." ${ }^{19}$

Sometimes certain general possessions were used by individuals, with or without permission. Of course, what belongs to the Sangha and what is owned by the individual monk is not always clear. Therefore, some sets of monastic guidelines detail how to deal with offerings: what a monk had to pass on to the authorities and what he could keep. The Fifth Dalai Lama writes in his chayik for the Nyingma monastery Gongra Ngesang Dorje Ling (Gong ra nges gsang rdo rje gling):

Whatever kind of payment that resulted from having gone to do home rituals, one may only deposit it with the monastic authorities, one is not to take it oneself. The distributions that have been directly given one can keep for oneself. When there are specific offerings made that serve the general good, then they should be collected as part of the "general offerings."

Terdak Lingpa, the author of the guidelines of Mindröl Ling and a contemporary of the Fifth Dalai Lama, is equally specific in maintaining the separation between what is the Sangha's and what can be divided among the monks: valuable offerings were to be kept as general assets, while others would be divided among the monks who conducted the rituals. ${ }^{21}$ 
Tsongkhapa in his guidelines for Jampa Ling (Byams pa gling) states that whenever monks got ahold of any goods or money, they needed to pass it or them on to the monastic authorities, ${ }^{22}$ suggesting that monks could not keep anything. ${ }^{23}$ The rules given above suggest that the individual monk was not to take possession of the Sangha's public property. However, the reverse practice sometimes occurred: "It is customary that the monastery monks' clothing is proper. Aside from that which is proper, one is not to wear anything inappropriate. If one is found wearing [something like] this, it will become [part of the] general assets, once it has been reported to the disciplinarian." ${ }^{24}$ The monastic authorities not only confiscated inappropriate goods in the possession of monks, but according to several chayik they also regularly took "illegal goods," such as alcohol, away from laypeople when they were caught with them on monastic grounds. ${ }^{25}$

With regard to the individual property of monks, it appears that while to own more than what the Vinaya allowed was tolerated, ${ }^{26}$ each individual monastery imposed its own restrictions on those possessions. One problematic type of property that features regularly in the monastic guidelines is that of livestock and horses. The monastic guidelines for Drepung allow certain monk officials to keep a limited number of horses and cattle, whereas ordinary monks are dealt with pragmatically: "if they are offered [such animals] they may take care of them for no longer than two months until they get sold." ${ }^{27}$ This statement not only shows that monks were given gifts that were-both theoretically and practicallyinappropriate, but also that the recipient of such an offering had the freedom to sell it, at least in the Drepung of the late seventeenth century. This concurs with Vinayic rules which stipulate that monks are not to refuse gifts, but it does not follow the examples given in the Mülasarvāstivāda vinaya in which monks are instructed to find a way to use these inappropriate gifts in a certain manner. ${ }^{28}$ Furthermore, the above ruling indicates that trade was not only tolerated, but sometimes also necessary.

As pointed out above, the income that the monastery received as an institution could only be used for certain purposes and was not used for the subsistence of monks. ${ }^{29}$ The chayik written in 1909 for all of Sikkim's monasteries specifies how this wealth was to be used:

The yearly monetary allowance for the monastery, ${ }^{30}$ the tax income from its monastic estates, as well as the income provided by donors in order to bring about merit for the dead and the living, and so on, need to be written in a ledger, specifying what came from where, instead of getting whittled away as has occurred previously. This [resulting] amount, which is kept in the monastic administration, should be used to restore cracked and aging walls on the inside and outside and to restore the receptacles of body, speech, and mind. ... The trust funds for the scriptures and other works should be developed without ever letting them deteriorate, by which each and every religious festival can continue. ${ }^{31}$ 
In Menri monastery in Tibet, the income that the monastic authorities generated with the herds they owned was also spent solely on the upkeep and adornment of the monastery's exterior. ${ }^{32}$ While in most cases it could not be spent to sustain the individual monks, we see that the monastery's surplus was meant to be used in a variety of ways. While it was intended to go toward the upkeep and expansion of the physical monastery and toward the financing of religious festivals and rituals, ${ }^{33}$ in reality it was also used to make business investments. This latter type of wealth management was under the auspices of the financial caretakers. Ekvall notes that they were required to manage the monastic wealth so that "at the end of their terms of office they may be able to report an increase in holdings and substantial earnings on wealth lent at interest or invested in trade operations." ${ }^{34}$ Hovden informs us that in the twentieth century in Limi, Nepal, the monastery there hardly ever used the grain that was collected as levy to feed the monks. Rather, this grain was lent out against interest to villagers in need of seed grain..$^{35}$ Regularly, however, some of the surplus was left unused.

As mentioned in the previous chapter, when monasteries consisted of several semi-independent subunits, in most cases distinct economies were kept. ${ }^{36}$ In a similar way, the economies of the Sangha and the individual monks were also strictly separate-at least this was the ideal scenario. ${ }^{37}$ The reasoning that is implicit in both the Vinayic materials and the monastic guidelines is that the monastery is dependent on the donor's decision concerning how his contribution will be spent. ${ }^{38}$ The sixteenth-century guidelines for Tsurpu appear to confirm this reasoning: "the desirous ones, who hear but not think, may not just hungrily consume the general assets of the Sangha. Rather, [the assets are] to be used continuously for whatever [they were] intended to be used for." ${ }^{39}$ Some donations that were offered to the monastery with a specific purpose were only meant for investment: the monastery could then only use the profits from that investment for that particular goal, which could be religious ceremonies or rounds of tea for the monks. ${ }^{40}$

\section{FINANCING AND SPONSORSHIP}

[T] he ascetic regime of the monk, though intended to remove him from lay society, in fact renders him dependent on that very society for material support.

-BUNNAG 1973: 30

In the case of Tibet, monasteries were both economically dependent on and independent from lay society. In Tibet, the Sangha was not the chief exemplar of nonreciprocity, as posited by Tambiah, nor was it a passive symbol of independence, despite its dependence on lay donors. ${ }^{41}$ Monasteries would not let their fate be decided by the whims of the laity. In fact, monasteries are regularly described as independent: "Since monasteries are exempt from tax and services they can be 
regarded as independent overlords, for they own land and serfs yielding them taxes and services, and discharge all the functions of authority (justice, etc.)." ${ }^{22}$ That said, in particular with respect to locally oriented monasteries, the strict conceptual divide between monastic and lay society was artificial at best.

In parallel to the narrative development of the Mülasarvāstivāda vinaya, the emic Tibetan account of the development of monastic economy tells a tale of monasteries initially being solely dependent on the king and wealthy aristocratic laymen. Eventually they inadvertently amass large estates, rendering them largely independent of outside sponsors. Dungkar Lopzang Trinlé, for example, remarks that during Songtsen Gampo's (569-650 or 617-650) reign "the monks, masters, and disciples were given a yearly allowance from the king's treasury, but other than that they owned nothing like fields, cattle, and pasture lands." ${ }^{43}$ Here, the monastics were portrayed as being dependent on the state and not directly on lay society. ${ }^{44}$

Certain scholars who research contemporary Tibetan monasticism regard putting monks on a monastic payroll as something that has come about in part due to the more recent Chinese overhaul of the economic situation of the monasteries and report that monks see this option as preferable to subsisting on the gifts of laypeople. ${ }^{45}$ A contemporary Tibetan-language work on monasteries in Central Tibet also notes that these days the more well-to-do monasteries give their monks a "dharma allowance," ${ }^{6}$ so that they do not need to go to the village to beg for alms or perform home rituals. The poorer monasteries cannot afford this, which is why their monks wander around the area to collect money. ${ }^{47}$

The sources at hand suggest, however, that the move away from donation dependency to a steadier income provided by the central monastic authorities (or government) was a trend that started long before the twentieth century. In light of the above citation on monasticism during the early Imperial period, one could even argue that living on a "state" income is one of the earliest, if not the earliest, monastic modes of subsistence for individual monks. Be this as it may, prior to the mid-twentieth century there was a gradual shift from monks being dependent on donations and income from ritual services to receiving allowances.

Earlier (pre-Ganden Phodrang) guidelines tend not to report on allowances, while later works occasionally report management changes concerning payment. ${ }^{48}$ In a set of monastic guidelines for the practitioners at the big protectors' chapel in Pelpung (dPal spungs) written in 1825 , we read that a certain type of allowances was newly introduced in that same year for the purpose of a stable field of merit, ${ }^{49}$ in particular for the recitations dedicated to the protectors. ${ }^{50}$ The monastic guidelines for Thekchen Damchö Gatsel ling written in 1898 (possibly by the Thirteenth Dalai Lama, as according to the colophon it was written in the Potala) have the stewards handing out the allowances..$^{51}$ This indicates that, at least in this case, the distributed supplies were likely to stem from income derived by the monastic authorities. 
These allowances tended to be food, not money, something indicated by the stipulation that "when one has taken one's allowances, one can only consume it inside the compound and not take it elsewhere." ${ }_{52}$ In later times, this allowance could be money as well. A chayik from 1949 states that a certain geshé made a donation to the monastery's office, which appeared to have been struggling, consisting of a "monastic allowance" of twenty-five silver coins ${ }^{53}$ for each monk on a yearly basis. ${ }^{54}$

The allowances some monks received should not be equated with stipends, i.e., income that anyone could be given regardless of their status, actions, or behavior. According to the rules on Tibetan monastic economy that can be extrapolated from the guidelines, it appears that there was no such thing as a free lunch. While in Benedictine rule-and in Chan monasteries in China-the adage "he who does not work, does not eat" may perhaps ring true, ${ }^{55}$ generally speaking one could say of the Tibetan context that "he who does not pray, does not eat." Not only because the authorities felt that allowances had to be earned by performing religious services and the like, but also because in most cases the tea, food, and allowances were handed out during the assembly and there were strict rules against passing these goods on to people who did not go to the assembly. ${ }^{56}$ The exceptions to this rule mentioned in many monastic guidelines regard those who are too ill to go, who are in retreat, or who are away performing duties on behalf of the monastery.

Some sources suggest that certain monastic authorities wanted to move away from payment during prayers in favor of rewarding educational efforts. A modern history of Tsurpu monastery suggests that monks serious about their studies had the right to a grain allowance, ${ }^{57}$ but only after they had offered another "enrollment tea" upon entering the formal education system. ${ }^{58}$ Kvaerne, relying on oral history, describes how in the Bon Menri monastery the head of the "office of education," who was chosen from among the geshés, was in charge of taking care of the monks who were studying debate. He would do this by going to the Jangthang area to collect butter from the monastery's herds. The revenue from this enterprise would also pay for the monks' provisions during the debates in the evenings, five days a week, all year long. ${ }^{59}$ Clearly, this type of subsidization was only available to monks who were enrolled in the curriculum.

Sidkeong Tulku, in writing his monastic guidelines for all Sikkimese monasteries in 1909, rules that the monks interested in learning had to be provided for economically. The text says that those who study diligently should always be given tea and soup by the central monastic administration until they complete their studies. ${ }^{60}$ The guidelines further state, with regard to those who have had some education: "Unlike before, [they] need to get a position and rewards and relief from tax, corvée duty, transportation duty and so on, commensurate with their achievements." ${ }^{61}$ 
In a similar attempt to increase scholasticism certain monastic officials at Drepung in the 1930 s created a new rule in which the payment of "the monastic salaries" was shifted to the debate ground instead of the previously favored assembly hall. This led to protests from a number of administrative monks who claimed that to change the rules was paramount to sacrilege. Eventually this resulted in an outburst of monastic violence. The Thirteenth Dalai Lama ended up expelling the ringleaders of both factions. ${ }^{62}$ An account by the once rogue monk ${ }^{63}$ Tashi Khedrup suggests that in Sera monastery too these changes were eventually implemented. He notes that on certain days, food and money were distributed at the debate ground and that some of his fellow ruffians would go and pretend to be involved in a debate, just to receive a share of the donations. ${ }^{64}$

It is clear that what the monks received as allowances was not always sufficient to live on, as evidenced by both oral history and textual materials. Monks supplemented this allowance with the distribution of alms they received, income from their own efforts (which could be ritual services, farming, or commerce), family support; therefore, in all, four types of income. ${ }^{65}$ Shérap Gyatso, an elderly monk who lived in Sakya monastery before the 1950s, notes with regard to the living standards then:

We monks were given allowances every year, which consisted of grain. With this we could do what we liked: we could make tsampa or something else. It was enough for a year, but it was not easy to live off just that. Some had help from outside, whereas others had absolutely nothing. ${ }^{66}$

Another monk who used to live in Yangri Gar in the 1950s describes what monks received from the monastery:
All monks would get allowances consisting of grains. We would mostly eat tsampa-paste. ${ }^{67}$ It was not much but enough to get by. We would go to do rituals ${ }^{68}$ and we could get some extra money and food. From that we could get butter and other things. At the assembly we would get tea and whatever sponsors would give us. We lived from hand to mouth. Some monks also had relatives to sponsor them, but my home was too far away. On a daily basis we would get tea four times a day, sometimes soup or rice gruel. Nothing nice like what you get these days. ${ }^{69}$

Elderly monks at Khampa Gar (Khams pa sgar) monastery in Eastern Tibet told one of my monk informants how they used to survive in Tibet. They bought butter and cheese from the nomads in a certain season and sold this later to the farmers for profit. They would also go to collect salt and sell it. ${ }^{70}$ This informant, Khenpo Chöying Lhundrup, does not think that this monastery used to have fields or rich sponsors. Monks needed to take care of their own food; this was the case even when he himself lived in Tibet during the 1980s and 199os and, he adds, is still the case. When he lived at the monastery sometimes food was handed out during the assembly, but not all the meals were provided. He reasoned that it was because 
the monastery was too poor to feed the monks. ${ }^{71}$ This may well have been the case, but Sönam Chögyel, a junior secretary at Sakya in India, states that in the comparatively wealthy Sakya monastery in Tibet there was no communal kitchen at the monastery, meaning that the monks had to cook themselves. He supposed that it was just the custom (lugs srol) to do it that way: it was not on account of the monastery being poor. ${ }^{72}$ While not all monks are aware of it, this custom is likely to stem from the separation between communal and private income and property.

A chayik written in 1934 by the Reting regent for Kunpel Ling (Kun 'phel gling) notes that on top of the allowances they received, prospective monks had to have secured their parental home's financial support. ${ }^{73}$ In Ladakh and Spiti, many monks were partially supported by means of so-called "monk fields." ${ }^{44}$ These fields were allotted by the monk's family upon entry to the monastery. The field would be managed by the family or by someone hired by the family. In Spiti, the monk had to provide the seeds but also received all of the harvest. ${ }^{75}$ In Ladakh, however, the monk was given a sufficient amount of grain, while the families retained the surplus. ${ }^{76}$ According to Carrasco, after the death of a monk, the field would be given back to his relatives. ${ }^{77}$

It is not the case, however, that all monasteries in Ladakh had this system of monk fields. Lobzang Döndrup, an elderly monk at Samkar (bSam dkar) monastery, informs us that such a system existed neither in Spituk nor in Samkar, whereas Hemis and Thiksey were well known for their monk fields. This suggests that there may be a difference in schools: the former two monasteries are Geluk, the latter two of the Drigung Kagyü ('Bri gung bka' brgyud) school. Spituk did own religious estates, although the revenue of those fields did not go directly toward the sustenance of the monks. ${ }^{78}$ This issue requires further investigation.

It can be safely assumed that these monk fields were not taxed. Particularly in the case where the family kept what the monk relative did not need, this system may have been a (rather modest) type of tax avoidance. This would further incentivize landholding families to make one of their sons a monk: not only, in the case of many sons, would the land not be divided up, but well-to-do farmers might gain a slight tax break. At the same time, one could argue that this arrangement maintained the ties between the household and the monk. ${ }^{79}$

A further implication is that only those boys whose parents owned land could become monks at monasteries in which this system was upheld. However, the term "monk field" may also refer to an arrangement of a rather different nature. Könchok Chönyi was made a monk at Phiyang monastery in Ladakh when he was eight years old. His father had died long before and his mother did farmwork. When he entered the monastery, he was given a monk field by the monastery's authorities. His relatives worked on it for him, something that he asserted was prohibited for monks. He was allowed to keep the harvest on the basis of which he was able to sustain himself. ${ }^{80}$ It seems that this system was not in place in Tibetan areas. ${ }^{8_{1}}$ This may in part be due to the nature of the ownership of land: people never 
actually owned land, they merely used it, since-at least nominally—everything belonged to the Dalai Lama.

Other information retrieved via oral history methods suggests that monks belonging to the larger Geluk monasteries in Central Tibet-during roughly the same time frame, the 1930s to the 1950s-did not have to worry:

Monks do not have material concerns about the future, about food or money, about taxes, about droughts or floods, for the monastery takes care of their basic needs. Monks get an allowance in kind and money, partly from the monastery and partly from the trust funds set up by laymen for the monks in a particular monastery. ${ }^{82}$

It may have been the case that monks in the Three Great Seats were given higher allowances also because of their close relationship to the government. ${ }^{8_{3}}$ Furthermore, the system of handing out these allowances could be seen as an attempt to gain greater control over the inhabitants of these massive monasteries. In the same way that, according to Carrasco, it was feared that Ladakhi monks would neglect to look after the welfare of the local population if they gained economic independence, ${ }^{84}$ the government may have tried to prevent the masses of monks, of whom the majority were not native to Central Tibet, from securing financial freedom.

\section{ON THE PAYROLL}

In connection to the allowances that monks received at certain monasteries, we come across an interesting phenomenon, the "allowance ledger." ${ }^{{ }_{5}}$ This appears to be a document that contained the names of the monks who were entitled to an allowance. It is likely that the amounts that were handed out were also recorded. One chayik from 1737 for the Amdo monastery Gonlung Jampa Ling (dGon lung byams pa gling) also contains a reference to an allowance ledger.$^{86}$ Here the reform suggested by the monastic guidelines was that allowances were not to be handed out annually but at the end of every Dharma session, i.e., four times a year, to prevent monks from only going back to the monastery every year just to collect what was due to them.

The earliest extant references to this type of record are from the seventeenth century. The Fifth Dalai Lama stipulates who was entitled to this allowance and the order in which people were to receive it:

When the allowances of the monastic main office are given out, then liaising with a government representative, one gives, according to the seal-bearing allowance ledger, first to the colleges and their studying monks, secondly to the unaffiliated residents and those from Gepel (dGe 'phel) ${ }^{87}$ and Ngülchu Chödzong (dNgul chu chos rdzong) ${ }^{88}$ thirdly, to the rest of the crowd who are in one way or the other affiliated, consisting of the riffraff, such as the kitchen aides. Those who have not gone through three debate classes, those who now study medicine and astrology, and the resident servants of the aristocratic monks are not included in the allowance ledger of the monastic main office. ${ }^{89}$ 
The above indicates who, according to the author, was deserving of financial aid. It perhaps comes as a surprise that the lower stratum of inhabitants, of whom the Fifth Dalai Lama was dismissive earlier in the text, was included among the beneficiaries while the students of medicine were not. Here, the allowances probably functioned to support the most disadvantaged: those who did not have the opportunity to do some business on the side. People who practiced astrology, medicine, or served an aristocratic monk already received an income and were thus excluded from receiving these allowances.

In 1876, Tashi Lhunpo too appears to have had one of these ledgers, called the Allowance Ledger of the Great Assembly. ${ }^{\circ}$ This document is mentioned in the context of how monks who served at other monasteries reintegrated back into the "mother" monastery after their term had ended. The text notes that upon leaving they were removed from this allowance ledger and explains what needed to be done to get back on it. ${ }^{91}$

In the guidelines written by the Thirteenth Dalai Lama for Thobgyel Rabgyé Ling (Thob rgyal rab rgyas gling) in 1913, it says that one was not to go against the main directives found in the allowance ledger and the rulebook regarding the distributions and the like, without a reason. ${ }^{22}$ The same author again refers to such a ledger in another chayik for Rongpo Rabten monastery in 1930. The relevant passage demonstrates that this allowance ledger was used by the managers of the offerings, to make sure that all donations ended up where they were intended to go. The presence of an allowance ledger suggests government involvement of some kind. While references to these ledgers are not uncommon, it is worth noting that none of the monastic allowance ledgers are currently accessible for research. ${ }^{93}$ They would make invaluable additions to our knowledge of the economy, the political relations, and the internal hierarchy of the Tibetan monastery.

The likely scenario is that the monasteries mentioned above, which are all Geluk, received state support, and were therefore obliged to keep a record of their income and expenses. ${ }^{94}$ This government involvement is also apparent in the monastic guidelines for Sera Je written in the first half of the eighteenth century. This text suggests that when the monastic authorities handed out allowances to the debating monks, which was a process supervised by stewards and disciplinarians, there also was a government representative present. ${ }^{95}$

\section{MONASTIC SPONSORSHIP THROUGH RITUALS}

The strict rules regarding the monastery's economic policy meant that not only was it theoretically forbidden for individual monks to use what belonged to the Sangha, but subunits within, or branches of, a monastery could not help each other out: a donation, as already mentioned, needed to be spent according to the donor's wishes. The large-scale sponsorship of certain festivals may have been not only a way to generate merit but also a way to distribute wealth more evenly. It is well 
known that the Ganden Phodrang paid for the performance of rituals that were seen to support the state (such as the Great Prayer Festival), but larger monasteries sometimes also paid their branches to undertake certain religious practices. An example of this is the nunnery of Rinchen Gang, which was a subsidiary of Sakya monastery. Its monastic guidelines suggest that this nunnery was financially not well off. Not only did some of the nuns have to go out to collect alms, they are also depicted as having to go out to weave and to work in the fields. Interestingly, nuns involved in doing certain rituals were remunerated by the (presumably Sakya) monastic authorities for their activities. ${ }^{96}$ This may have been a way of legitimizing Sakya's sponsorship of the struggling nunnery.

The chayik names the amounts that had to be given to the nuns during or after events specified on the ritual calendar, such as the maṇi retreat, the monthly Tārā memorial service, ${ }^{97}$ and the ritual fast..$^{98}$ The text specifies exactly what had to be provided by whom. In some cases, it was the monastic authorities and in others it was the lay headmen. ${ }^{99}$ This text then not only contains guidelines for the nuns to abide by, but also serves as a kind of contract in which the economic survival of the nuns was safeguarded. Interestingly, it also involves the cooperation of a headman, who was burdened with soliciting donations from his constituents. It is noteworthy that-as indicated above-none of the contributions the nuns received were given out without there being some kind of religious reciprocation. In many respects, this particular chayik resembles documents that contain endowments of funds ${ }^{100}$ for particular monasteries. Another set of guidelines, written in 1728 by Rigdzin Tsewang Norbu (Rig 'dzin tshe dbang nor bu, 1698-1755), details not only with what the lay donor endowed the monastery in question, but also what kind of rituals he expected the monks to perform in return for the donation. ${ }^{101}$ This indicates that occasionally the chayik also functioned as a contract between the donor and the recipient, containing the exact stipulations of the terms and conditions of the endowment.

\section{THE LAMA'S RESIDENCY AND ESTATE}

No discussion of Tibetan monastic economy would be complete without referring to the institution of bla brang. In Chapter 3 I pointed out that this term does not always refer to the autonomous units affiliated to a monastery but owned by an incarnation; it also can simply refer to the monastic office in charge of (economic) management. The residencies that were headed by incarnate lamas usually maintained independent economies. However, most of these were neither very big nor wealthy. The smaller residencies did not hold any estates. ${ }^{102}$ The incarnated lamas who had a good reputation often won sponsors. They then built their own residences and sometimes even entire monasteries or hermitages, "all of which were under the direct control of the Lama," not the affiliated monastery. ${ }^{103}$

A major source of income for Tibetan monasteries was-and perhaps is even more so today - the presence of one or more incarnations. Religious figures of a 
certain standing often were an object of veneration for the general populace, thereby generating donations on a large scale. After the death of a prominent incarnation, the monastery not only lost a religious leader but also a significant source of revenue. This appears to have also been the case in Chinese monasteries during the Song dynasty, despite the obvious absence of the incarnation system. According to Walsh, monks who possessed religious authority, usually the abbots, attracted large sums of donations that they in turn would donate to the monastery. ${ }^{104}$

While the estates of the wealthier residencies were occasionally the topic of certain political altercations, we can deduce from the-admittedly scarce-available information that the presence of a lama who managed to attract wealth can be seen as providing flexibility in a monastic economic system that was resolutely rigid. A lama's wealth could be spent where and when he deemed it most appropriate. ${ }^{105}$ Stein also notes this feature but only connects it to more recent times (i.e., post1950): "In the modern period ... the 'living buddhas' (incarnate lamas in Chinese parlance), as opposed to the monasteries, regularly made distributions of alms, once a year, amounting sometimes to half their capital, and contributed to the costs of the religious ceremonies of their monastery and the state." 106 Thus, while one branch was "legally" not able to give financial aid to another belonging to the same monastery, a lama was at liberty to help out struggling subunits, in order to help the monastery to which he felt an allegiance.

\section{MONASTIC LANDLORDISM}

The Rules for Sera Tekchen Ling (Se ra theg chen gling rtsa tshig) was probably written in $1820 .{ }^{107}$ It was meant for the whole of Sera monastery and authored by the second Tsemön Gyaltok (Tshe smon rgyal thog) - the then-regent of Tibet. The work directs itself only to the monastic officials. ${ }^{108}$ It speaks of how the managers of the subjects on the monastic estates have misbehaved:

To let all the leading positions, such as that of estate manager, ${ }^{109}$ be filled by those who are close to oneself and law-abiding, would mean an instatement that is both wise and encouraging, [thereby avoiding] the oppression that has so far been a cause for the monastic estate's subjects to become scattered. One needs to encourage [them] to manage the lands with good motivation, making sure that the Sangha's income and provisions not deteriorate. There were a couple of general managers and treasurers with bad habits who were involved in private enterprises and many other things. Having caused many monastic estate subject families to abscond, they took hold of their lands and made servants out of the few remaining scattered and destitute subjects. When these people, who just did as they pleased without any regard for the two systems, ${ }^{110}$ were found out, the only appropriate option was to banish them to a faraway place. ${ }^{111}$

This passage demonstrates that the managerial strategies that Sera monastery maintained were much like those of the lay landlords. It appears that in particular 
in the nineteenth and twentieth centuries, agricultural laborers were a scarce commodity in Central Tibet. Thus, one had to treat them relatively well, if only to prevent them from running away. These monastic guidelines suggest that previous estate managers had abused their position, ultimately leading to financial losses for the monastery. As punishment they were exiled, not expelled, which may be an indication that the perpetrators were laymen. Be that as it may, the ultimate responsibility lay with the monks who appointed them, which can be gleaned from the advice given on how to select these estate managers.

The text continues, suggesting that this was not just an isolated incident, but an ongoing problem: "Those who send out the provisions let the surplus of the harvest and the profits go toward [their] allowance and good tea, and do not send any to the Sangha: they hoard by expanding and collecting it. There seems to be rather a lot of people who do this." ${ }^{112}$ The work goes on to suggest that certain monk officials were involved in accepting bribes, which then is thought to make the general discipline of the Sangha impure. The author exhorts the readers to keep to precedent: "One is definitely not allowed to deviate from the old to the new and be greedy and belligerent and so on, which will become causes for disharmony, rifts, and fights among members of the Sangha." ${ }^{113}$ The emphasis on precedent is striking here. While the author of these guidelines in effect encourages change, the change is geared toward reestablishing the previously agreed rules. More generally, the author's primary concern is not the direct welfare of the subjects, who were obviously mistreated by the estate managers, but the long-term income of the monastic community of Sera.

\section{PROPERTY AND INHERITANCE}

It is remarkable that the chayik that I have come across do not report on issues of inheritance. This could indicate that when an ordinary monk died, there tended to be no noteworthy problems with regard to dividing his property. ${ }^{114}$ This leaves us largely dependent on eyewitness accounts. In the Mūlasarvāstivāda vinaya specific rules were made to keep monastic property "in the family, to prevent it from falling into lay hands or the state." ${ }^{115}$ Similarly, according to the katikāvatas, in Sri Lanka, a monk's property would become the Sangha's after death or giving up robes. ${ }^{116}$ In more recent times, in Thailand, it is said that according to state law, upon the death of a bhikkhu - unless he has set up a testament of sorts-all his possessions go to the monastery, as it is seen as his home. ${ }^{117}$ The willing of one's property to laypeople does not seem to have been an option in the Mülasarvāstivāda vinaya, but a monk's things could go to a layman when there was a "fiduciary deposit,"118 which I take to mean a fund, owned by the monk, but managed by a layperson. In the Chinese twelfth-century Chan monastic rulebook, the Chanyuan qinggui 禪苑 清規, it says that the dead monk's possessions were auctioned (presumably among 
the monks). The profits were then used for funeral and religious practices for his benefit, such as sütra readings. The text stipulates that a monk should not have too many things - which would make the auction tedious - nor too few, to avoid his funeral having to be paid for by others. ${ }^{119}$

In the Tibetan case, again there does not appear to be a single ruling on what to do with the inheritance of a deceased monk. ${ }^{120}$ In Sakya monastery, monks could will their property, and in absence of a will their families could claim the monk's possessions. ${ }^{121}$ Shérap Gyatso, who used to live there, further specifies this and indicates that the family was indeed involved but that they would usually not keep the things for themselves:

If an old monk would die his relatives would sell his things and often spend the proceedings on the funeral costs and rituals, and so on. If he had no relatives the monastery would do this. There were very few monks who really owned something; most did not have a lot, much unlike monks these days. ${ }^{122}$

Similarly, a report on Spiti from 1897 informs us that when a monk died, his property did not go to the monastery but back to his family. The first recipient would be another monk in that same household, but in the absence of someone like this, it would go to the head of the household. ${ }^{123}$ In many cases a monk had to "buy" living quarters at the monastery, and a younger monk-often his relative-would oftentimes join him there. ${ }^{124}$ Regularly when the older monks died, these younger monks would inherit this "household." 125 With regard to monasteries in Eastern Tibet, Ekvall states that a monk's possessions would become the community's after his death. ${ }^{126}$ Khedrup recalls that in Sera Je, when a member of the society of "rogue monks"127 died, one share went to that society, some was used to pay for funerary costs, and the rest was given to the college to which he belonged. ${ }^{128}$

Due to lack of primary (and secondary) sources, we cannot be conclusive about what happened when ordinary monks died. It can be gathered from the above accounts that the average monk did not own much, at least not enough so as to anticipate serious complications with regard to his inheritance. What the monk left behind was-much like in today's Tibetan communities-used for the performance of the necessary death rituals. Thus, regardless of whether it was the family or the monastery spending the money, eventually all flowed back to the monastic community, whether it be into the pockets of the monks or the coffers of the monastic government.

Naturally, inheritance also worked the other way around. That is to say, monks also inherited. ${ }^{129}$ Or did they? Again, this is not entirely straightforward. According to some, monks were not allowed to inherit land. ${ }^{130}$ French states that monks and nuns could inherit land, but never the primary family land. ${ }^{131}$ According to Cassinelli and Ekvall, monks had the same rights as laymen over "movable possessions" - which is to say, anything but land. ${ }^{132}$ In any case, living off one's parents' inheritance was not a common method of subsistence. 


\section{BUSINESS AND TRADE IN AND AROUND}

THE MONASTERY

Tibetan monks and monasteries have probably always been involved in trade. Monks and merchants made natural bedfellows: neither was inextricably tied to land or locality. They were not bound to stay in one place, as the farmers were. Moreover, monks and traders regularly traveled together for safety reasons, ${ }^{133}$ and often pilgrimage and business went hand in hand. Due to their monastic affiliation, monks could have networks that were far-reaching, facilitating trade across the board. Chen, speaking on Kham, supposes that the economics of "the lamasery" was "not so much based on land as on trade and usury." ${ }^{134}$ Michael estimates that thirty percent of the (Central Tibetan) monastery's income came from "trade, business and banking activities, such as money lending and investment." ${ }^{135}$ This involvement in trade is seen by many as a transgression of monastic vows, as all the different prātimokșas have a ruling against buying and selling. ${ }^{136}$ But was commerce really forbidden? At the beginning of the eighteenth century Desideri remarks:

According to their rule monks are absolutely forbidden to engage in trade or commerce. Nevertheless, this rule is commonly-or rather almost universally-disregarded. They are very active and interested in business dealings, and for that purpose they obtain leave from time to time to go on journeys and to absent themselves from the monastery for a certain period. ${ }^{137}$

While this missionary's observations are normally rather well informed, the perceived strict taboo on trade in (Tibetan) Buddhism rests on a misunderstanding or a misinterpretation. Nonetheless, this distorted view on monastic trade has pervaded the thoughts and minds of scholars and nonscholars alike to this day. This notion added to the-once pervasive-view that Tibetan (monastic) Buddhist practices are diluted or debased versions of what was once current in Buddhist India.

That Tibetan monks obviously engaged in trade does not mean that Indian monks did not. The Mülasarvāstivāda vinaya, for example, depicts monks storing rice and selling it when it became scarcer. ${ }^{138}$ According to the same corpus-being arguably the most lenient of the Vinayas with regard to financial matters-buying and selling is fine, provided one does not seek gain. ${ }^{139}$ The relevant passage from the Vinayavibhainga can be translated as follows: "There is no transgression [regarding] a bhikșu both selling without seeking gain as well as him buying without seeking gain." ${ }^{140}$

The monastic guidelines demonstrate a diverse range of attitudes toward trade. Sometimes, the Tibetan texts reiterate the Vinaya rules and at other times they diverge considerably. One of the earliest texts in this genre mentioning trade was written by Chennga Drakpa Jungné (1175-1255). He was the fourth abbot of Drigung Til, for which this chayik was composed. The author held that post from 
1235 to 1255 , suggesting that this text is likely to have been composed within this time frame. Concerning monks' business, he writes: “Those monks who, under the false pretext of going to Kyishö (sKyi shod) and Yorpo (g.Yor po) and other places for business or on an alms-round, are found to drink alcohol, should be punished, for they are the enemies of the Teachings. They are not allowed back to Til." ${ }^{141}$ This section is significant for a number of reasons. Going to do business is mentioned together with collecting alms. ${ }^{142}$ It is a casual reference: there is nothing wrong with being involved in trade. The problem here is drinking alcohol, not doing business. ${ }^{143}$ Generally speaking, the monastic organization in this earlier period was demonstrably looser and monks were more likely to be self-financed. Often, they were also not necessarily attached to a single monastery.

Later chayik demonstrate a less casual attitude toward trade. The monastic guidelines for Sera Je, written in the 1737 , note that when one is healthy and intelligent, "it is not permissible to live a life of ease and do business for profit or to give out loans of barley." ${ }^{144}$ This statement suggests that the mind is a terrible thing to waste, in particular on something as frivolous as business. It also does not categorically forbid trade and providing loans-activities that perhaps would be more permissible for dull-witted monks.

In a similar vein, it is reported that at the Sakya branch monastery of Dongga Chödè (gDong dga' chos sde), ordinary monks were allowed to do business, whereas monks of "the highest order" were forbidden to engage in these mundane affairs. ${ }^{145}$ The detrimental effect of commerce on the mind is also noted by Patrul Rinpoche in the early twentieth century, who complains: "Lamas and monks these days see no harm or wrong in doing business; indeed, they spend their whole lives at it, and feel rather proud of their prowess. However, nothing debilitates a lama['s] or monk's mind more than business." ${ }^{146}$ Not only was trade seen as debilitating, but by being involved in commerce one also puts oneself on a par with laypeople. The Eighth Panchen Lama remarks: “These days there are many who-under the impression that they are following in the footsteps of Saakyamuni Buddha-despite having been freed from the household, still have not been freed from householders' activities and thus do much trading for profit." ${ }^{147}$

Interestingly, during the first half of the twentieth century, the polymath Gendün Chöpel (dGe 'dun chos 'phel, 1903-1951) linked the recent rise in monastic commercial activities in Amdo with the inability to keep the vows of celibacy correctly. ${ }^{148}$ The monastic guidelines for Drepung by the Fifth Dalai Lama-on which the above-cited Sera Je chayik is based and from which certain sections are taken nearly verbatim-give another ruling on trade. This text conveys similar sentiments, but from a slightly different angle: "It is not allowed to pretend to be a debating monk, and while being healthy and intelligent, to not study but [instead] to do business for profit and make loans of barley." ${ }^{49}$ Here it is important to note that the reason why the Fifth Dalai Lama had a problem with debating monks 
doing business is not just because it would be a waste of their talent, but because earlier on in the text he ruled that registered debating monks were to receive an allowance from the monastic authorities. This means that if they would involve themselves in trade and not study, they would be receiving that "salary" illegally and in addition to the returns of their business enterprise.

A set of monastic guidelines from 1900 states that one needed to be given permission to trade: "Whether the trade is on a big or a small-scale, one is not to engage in trade without asking the monastic authorities or the disciplinarian. Do not use bad weights and measures." ${ }^{150}$ Again, what we see here is not that tradebuying and selling - was forbidden outright; it simply needed to be regulated. Ideally, it was to serve a purpose other than greed.

\section{COMMERCE: THE INDIVIDUAL VERSUS THE WIDER MONASTIC COMMUNITY}

In the chayik, when restrictions with regard to business are imposed, they are always directed toward individual monks, never toward those who accumulate wealth on behalf of the monastery. As mentioned above, this distinction between the individual personal livelihood and the larger corporation of the monastery is generally very pronounced. This distinction has its roots in the Vinaya. ${ }^{151}$ Gernet, who studied the Mülasarvāstivāda vinaya in Chinese, remarks that "commerce is ... prohibited to the monks but recommended to the Sangha." ${ }^{152}$ In the monastic guidelines this separation of the corporate and the individual is pronounced when treating how to divide donations, but also when it comes to rules on trade and other "work." The chayik for Ramoche monastery, which was written in the 1740s, states: "Except for the benefit of the monastery and the monastic official lamas' fields, the monks are not to conduct trade, work in the fields, or give out loans and so on." ${ }^{153}$

A similar sentiment is expressed in the set of monastic guidelines for Pabongka hermitage: "Except for the officials who work for the general Sangha, no one else, whether high or low, may keep horses and cattle, do business and give out loans against interest, interfere in the matters of laypeople that are inappropriate, and carelessly wander about, and so on."154 Similarly, the chayik for Ochu Gon ('O chu dgon) from 1918 states: "Except for the managers, it is not allowed for the general monk populace to do business and make loans against profit. It has been said by the Victor(s) that it is impossible for those who have gone forth to be lacking in sustenance. Therefore, do not do things that go against the rules."155 This is reminiscent of a Bhutanese saying: "Monks sustain themselves by means of rules." ${ }^{156}$ This proverb reflects the very widespread (and still current) notion that as long as one lives a virtuous life, one need not worry about one's livelihood. A similar sentiment is reflected in the sixteenth-century monastic guidelines for Tsurpu: 
In particular, one needs to give up on fearful thoughts that one will be overlooked, thinking: "what will happen when I run out of food and clothing?" According to many texts, excessive attachment and craving need to be abandoned, as the books state that when one relies on the continuity of the Dharma, shortages will be impossible. ${ }^{157}$

Sometimes, the line between the monastery's affairs and the individual monk's business became (intentionally) blurred. The Drepung monastic guidelines report that on occasion there had been:

some greedy teachers, who would go to Lhasa on official business, not hiding the fact that they were Geluk, and pretended that what they received went solely to their college. They would put a seal on the goods and their own living quarters would be full of them. Those items have now turned up and it is obvious that they should wholly go to the big colleges. These actions are a total embarrassment and should thus not be done. ${ }^{158}$

Similarly, the monastic guidelines for Tashi Lhunpo first mention the monks who were trusted to conduct the monastery's business and then state:

Also, others who are astute will mingle with this crowd [of business monks] and involve themselves in making profits through trade and give out loans of money and grains against interest on a large scale. Furthermore, some creditors, in dealing with people who shamelessly default on their loans and interest, pretend that the investment capital of the monastic office is involved. To pursue them aggressively and the like is to be on the verge of [committing] many wrongdoings. ${ }^{159}$

Again, the problem that the Eighth Panchen Lama, the author of these guidelines written in 1876 , articulates is that monks doing business for themselves may become indistinguishable from monk officials. When pursuing debt defaulters, one could profit from being perceived as a monk official-only then could one apply pressure by making the debtors believe the money owed was actually the monastery's investment capital. Obviously, people were more inclined to pay back money that belonged to the Sangha than to an individual monk. The same author is also rather strict about business carried out by individual monks:

While the elders and their assistants at the college may use the monastic office's investment capital to give out loans against interest, none of the ordinary monks, whether old or young, may ever be involved in such things as loaning out grains and money against interest or do things that fall under doing business and making loans for profit, such as hoarding, horse-trade, donkey-trade, or things like managing acquired fields. Rather, they should prioritize the practice of the various stages of Dharma: study, contemplation, and meditation. ${ }^{160}$

Here the author strongly opposes any business conducted on an individual level. Elsewhere in the same text he demonstrates his aversion to the "worldly" behavior of his monastery's monks: "One should never manage fields, use cattle, hoard, give out loans and so on. This is turning one's back on what a monk is meant to do."161 
This is in many ways similar to the rules on trade in Menri monastery: "Activities that lead one to the worldly life: trading in order to obtain profit, lending money for interest, deceit in making weights and measures and breaking sworn oaths. It is acceptable to make an honest living by petty trade, following the rules of the state." 162

We thus find that the guidelines stipulate rules on who could do business as well as on how it was to be conducted. As some of the texts cited above suggest, commercial activities could also give rise to dishonesty, in particular with regard to the measures and weights used. Again, the guidelines for Tashi Lhunpo state:

Considering that the Dharmarāja Songtsen Gampo has prohibited fraud to do with weights and measures for laypeople, does it need mention that we, who have gone forth, should also not be doing this? Previously, from within the ranks of the monks enrolled here, there have been cases of people swindling others by means of incorrect weights. Obviously, this brings about very heavy negative karma! Taking into consideration that this is a disgrace to both the general and the specific Teachings, as well as to the community of the Sangha, no one-be they young or old-may do this from now on. If there are people who have done this, they need to be punished severely after the faults have been established on the basis of investigation by the 'religious rules office. ${ }^{163}$ It is said in the collected works of the Kadam masters that: "Even in the ocean-like community of those who have been instructed, if the rules are relaxed only slightly, hooved and fanged beasts with faulty discipline will appear."164

It is telling that here the author refers to what can be translated as "secular laws,"165 namely those that are purported to have been established by Songtsen Gampo in the eighth century. His laws were thus seen as applicable to the whole of the population in Tibet, and not just to laypeople. Another text also comments on where commercial activities should take place:

A lot of unnecessary trading should not be done. When it is done, the price should be according to what is current; one should not go higher or lower than the current rate. One should not be obsessively attached toward business that has not yet been finalized. ${ }^{166}$ Trading should be done outside the gate and nowhere else. ${ }^{167}$

Schram also notes that when business deals were made by monks, they were not to be made too ostentatiously. ${ }^{168}$ Similar rules can be found for the Japanese Zen monastic context in Dōgen's (1200-1253) Eihei Shingi, in the section entitled "Regulations for the Study Hall." Here it is said that monks were not to talk to tradesmen in the study hall, but to do this elsewhere. ${ }^{169}$ This suggests that trade by monks was both conducted and tolerated, but not in a place reserved for the study of the Dharma. ${ }^{170}$

Because the chayik indicate that trade by individuals was sometimes seen as a problem and sometimes as being in need of regulation, one may conclude that business was conducted by many monks throughout the Tibetan Buddhist world (and beyond). However, Miller, who did fieldwork in the 1950 s in the Himalayas, 
reports that the Bhutanese saw trade by monks and monasteries as something typical of Tibet. The Bhutanese themselves deny that their monasteries were ever involved in trade. ${ }^{171}$

While, as noted above, some monks managed to exchange butter for grains and made a small profit from such exchange, for extensive trade one needed startup capital. ${ }^{172}$ According to Shérap Gyatso, most monks did not really do business for this reason. He adds that to be successful one needed to be business-savvy, which most were not. Monks who had both the capital and the financial know-how were-in his experience-rare indeed. ${ }^{173}$

Overall, when reading these monastic guidelines through a wide lens, both diachronically and synchronically, we can see a shift from a reasonable tolerance with regard to trade to a less understanding attitude. This decreasing tolerance toward commercial activities is, I believe, strongly related to the gradual change in the economic policies of many monasteries. The Ganden Phodrang government greatly increased the state sponsorship of certain monasteries. ${ }^{174}$ Therefore, from the late seventeenth century onward there appears to have been a greater push, incentivized by the government, toward providing individual monks with their upkeep, at least partially. ${ }^{175}$ In particular in the twentieth century there were multiple attempts to provide monks with an income, but only in exchange for an interest in education, good behavior, and allegiance to the Dalai Lama.

At the same time, when we view the rulings on trade in context, it appears that the choice of individual monasteries to either restrict or to (tacitly) allow trade also had to do with the specific circumstances they found themselves in. In the case of Tashi Lhunpo in the late nineteenth century, we learn by reading the monastic guidelines that it was an institution that held great prestige and had no problem with its monk enrollments. This text contains policies geared toward curbing monastic growth by being selective. To categorically forbid commercial activities can also be seen as one of those policies, for one would only attract those monks who were not dependent on trade to begin with. For smaller monasteries, it was simply not feasible to prohibit trade: the only thing that they could do was to regulate it.

\section{SERVICING LOANS AND LOANSHARKING}

As has been shown above, trade and giving out loans against interest are often mentioned in the same breath in the monastic guidelines. It has often been remarked upon that in old Tibet the monasteries were the biggest "money" lenders. ${ }^{16}$ From a financial perspective, this is a logical process as (the monastic) trade provided a surplus that could subsequently be invested. ${ }^{177}$ The rules applying to loans were very similar to those applying to trade: individual monks were often discouraged from giving out loans, whereas monasteries often functioned almost 
as modern-day banks, making investments and giving credit, without monastic authors ever expressing their dismay over these "usurious" practices. It can even be argued that, when one considers the financial relationships between donor and recipient as portrayed (among others) in the Vinaya, giving out credit is a more reasonable and more widely acceptable method of sustaining the monastery's financial health than trade. Before turning to the above-outlined issue, the role of individual monks as creditors should be briefly discussed.

Among the reasons monks are discouraged or even forbidden from being involved in giving out loans is that, at a certain point in time, these loans along with their interest need to be retrieved. There is then a danger of monks exercising force in the process. ${ }^{178}$ In one of the earliest sets of monastic guidelines, the issue of monks (aggressively) pursuing payments due is already noted as a problem. The chayik for the community at Densa Til (gDan sa mthil) was written by Jigten Sumgön (1143-1217) during or directly after a period of famine. ${ }^{179}$ The relative poverty of both the lay population and the monks is pronounced. He therefore warns monks not "to pursue traders for old debts; not to ally oneself with 'strongmen' from among the destitute country folk and then to chase people who have longstanding debts; and not to pursue them one by one, come what may." ${ }^{180}$ While the language of this text is abstruse, there can be no doubt that this author felt that monks were attempting to retrieve their outstanding loans at a time of great scarcity, and he chastised them for doing so.

A somewhat later chayik by the Eighth Karmapa (Mi bskyod rdo rje, 1507-1554) connects debt, whether on the part of the creditor or the debtor, to deceit and theft: "Furthermore, tying [someone else] up in a loan, not repaying one's debts, and being deceitful when it comes to selling foodstuffs must be abandoned in every way. Then one can prevent the causes that lead to the downfall ( $p \bar{a} r \bar{j} j i k a$ ) of stealing." ${ }^{181}$

The individual enterprise of both lending and borrowing was, according to Cassinelli and Ekvall, not restricted by Sakya monastery in the first half of the twentieth century. Rather, when engaging in these types of practices the monks operated under "royal law." 182 This certainly was not always the case, for in Mindröl Ling monastery during the late seventeenth century, for example, a monk caught privately lending against interest would risk losing that which he had loaned out:

The giving out of loans by individuals should not be done, because it is a distraction and it is unstable, and because it is a cause for becoming degenerate, without ever being satisfied. If you do this, then the thing that one has loaned out will become communal property. However, this is not forbidden if one loans out something to those in need, without getting a profit out of it, as long as it is not an excessive amount. ${ }^{183}$

Contrasting the restrictions individual monks experienced with regard to giving out loans, it was mostly unproblematic for the monastery to lend out property on behalf of the Sangha. The Vinayavibhanga, to which the Tibetans had access, 
appears not just to tolerate monastic communities collecting interest but to encourage it: "The Bhagavan decreed that the goods in perpetuity ${ }^{184}$ [given] to the Buddha, Dharma, and Sangha should be given out on loan. ${ }^{185}$ The resulting interest needs to be offered to the Buddha, Dharma, and Sangha." ${ }^{186}$ As to be expected, here a proviso with respect to lending against interest is given, namely that the profit needed to be offered to-or "reinvested in"-the Three Jewels. We see this "rule" on giving out loans adhered to in the Tibetan context. In essence it means that all profits from monastic enterprise (be it interest from loans or investment) would flow straight back to the monasteries, but in what form is not entirely clear. In other words, we do not know exactly what the revenue was eventually spent on. Was it to be spent on the monks, to go toward the monastery's upkeep, did it go straight into the monastic coffers, or was it used to make extensive offerings?

The Ksudrakavastu offers a narrative in which a merchant pledges to the monks a certain amount of venture capital. The merchant then proceeds to invest the capital on the monks' behalf, and any profit made from the capital he then distributes to the monks, who also continue to own the capital. ${ }^{187}$ In this instance, then, it is the individual monks, albeit as the Sangha, who profit. From the sources under consideration here it can be gleaned that Tibetan monks usually did not directly profit from the monastery's entrepreneurship. However, there were certain ways to circumvent this, other than by spending it on specific rituals. ${ }^{188}$ The chayik for Chamdo Ganden Thekchen Jampa Ling (Chab mdo dga' ldan theg chen byams pa gling), written in 1933 by the Thirteenth Dalai Lama, gives us a glimpse of this process:

The monastic authorities, represented by the managers of the private and collective offerings, ${ }^{189}$ need to give out loans and make business investments and the like using the older offerings for investment or newly received wealth, in a careful and considered manner. One is to increase and not to let decline [this money] without any changes in the procedures. The distributions, whatever they are, need to be given out when the recipients of the offerings are thought to be the largest number. One should not allow the continuity of offerings to decline and be neglected, letting the gifts deteriorate. ${ }^{190}$

Here the managers are encouraged to invest the wealth and distribute the profits from these investments at a time when most monks would be able to benefit. The alternative was to let the offerings go to waste. That the Thirteenth Dalai Lama felt the need to point this out, however, in fact suggests that the reality was otherwise: that, indeed as several other accounts suggest, many monasteries tended to hoard goods, rather than to use or invest them wisely. The above process is confirmed by an account-based on oral history - which suggests that in the first half of the twentieth century the profit from investments was regularly used to buy perishable goods, such as grain and butter. These products, subject to decay, were thought of as unsuitable to invest further. ${ }^{191}$ Presumably, this was a way to actually use the 
profit. This was not the norm, however: Tibetan monasteries had a tendency to hoard goods-I suspect exactly because of the Vinayic restrictions given abovewhile the monks present at the same monastery regularly experienced relative economic hardship.

The interest rate on monastic loans is reported to have been rather high-the highest interest rate was about twenty-five percent per year. ${ }^{192}$ Chen states that, much the same as in contemporary finance, larger loans carried lower interest rates whereas smaller loans had higher interest rates. The rates on grain loans were higher than those on cash loans. The interest paid per annum on cash loans was around fifteen percent. ${ }^{193}$ In fact, it is claimed that the monasteries tended to charge interest that was higher than that of the government. In Ganden, for example, one would borrow four measures of grain and eventually pay back five measures. But to borrow with the government was to borrow ten measures and to pay back eleven. ${ }^{194}$ It is not that the prospective monk lenders would get lower rates than laypeople, however. A loan contract from an earth dog (sa khyi) year ${ }^{195}$ suggests that a monastic house at Drepung Loseling (Blo gsal gling) loaned five hundred silver coins ${ }^{196}$ against a yearly interest of eighteen percent. ${ }^{197}$

Unsurprisingly, loans were not accessible to all. Monasteries often would not deal directly with the poorer households, possibly because this was seen as too risky - a loss made with offerings of the faithful would amount to squandering the Sangha's possessions. Regularly, the debtors of the monastery were the well-todo families who occasionally passed on smaller segments of the loans to the less affluent. ${ }^{198}$

That monasteries gave out loans and became de facto debt collectors must have added to tensions between the monastic and lay populations-particularly the higher strata of society. Above we saw that collecting the interest or the debt posed a threat of violence. The debt collectors of Ganden in the first half of the twentieth century were not permitted to use physical violence. They would visit the families of those in debt to ask them to help with repaying the money. Here then the method was social pressure rather than threatening punitive action. ${ }^{199}$ In Chinese monasteries during the same period, the last resort when dealing with people defaulting on their debts was to hire a couple of ruffians to dismantle the door and take away the furniture. Another option was to take them to court, but this was less common. ${ }^{200}$ Similar practices were also employed in the Tibetan monasteries-with the ruffians often being monks. ${ }^{201}$ That this occurred did not mean that it was acceptable behavior. In Tibet in the 1930s, monks from Sera monastery had resolved debts by seizing goods. The Thirteenth Dalai Lama ended up fining Sera's abbot for this, implying that the abbot was held legally responsible for the conduct of his monks. ${ }^{202}$

In contemporary Tibetan monasteries loans and business investments are still made by the monastic management. Until recently the larger monasteries in exile in South India loaned money to Tibetan sweater-sellers so the latter could buy 
their materials. When one year the sellers defaulted on their loans, the monksnot willing, or able, to take their fellow countrymen to court-took no action. The monasteries ended up losing a lot of money. ${ }^{203}$ Some monasteries in the PRC still loan grain out to those families who need it, but without any interest or deposit. Again, no measures, legal or otherwise, can be taken when it is not paid back. ${ }^{204}$ Contrasted with the manner in which the monastic authorities dealt with debt collecting prior to the 1950s, this is clearly indicative of the changed power relations between the lay populations and the monastery.

\section{USURERS OR BANKS: MONASTICISM AS AN \\ ECONOMIC MODEL?}

Perhaps Buddhist monasteries ... acted as agents of economic development in much the same way as the monastic foundations of medieval Europe.

-STRENSKI 1983: 474

I now return to an issue alluded to above, namely that providing loans and making investments were methods of wealth accumulation that were less problematic for the monastic agents than, for example, trade or owning fields. When reading theoretical works on the ethics of commerce and finance that have a strong focus on Western religious and philosophical discourses, we are informed that, generally speaking, trade is inevitably good, for it is a simple exchange, whereas moneylending is morally reprehensible. This is regularly presented as a universal truth. The practice of lending money and charging interest is equivalent to the more archaic usage of the word usury. ${ }^{205}$ In Christianity, usury has traditionally been seen as a grave sin. It has been described as either theft from people or from God. Thomas Aquinas saw it to be a sin against justice, a notion probably inspired by ancient Greek thought, according to which usury was seen as something despicable. ${ }^{206}$ Aristotle contends the following: "The most hated sort, and with the greatest reason, is usury, which makes a gain out of money itself. For money was intended to be used in exchange, but not to increase at interest. ... That is why of all modes of getting wealth this is the most unnatural." ${ }^{207}$

In Tibetan Buddhist societies, when considering the sources at hand, on the whole commerce is never described as preferable to moneylending: they are seen as equally bad (or good). Moreover, when the Sangha is the moneylender, it is even encouraged. As has been demonstrated above, according to the Mülasarvāstivāda vinaya, the Sangha is to use money (or otherwise) in a manner that is exactly contrary to Aristotle's views: the Sangha preferred not to use the offerings of the faithful in exchange, and instead tried to increase the offerings through interest. The Buddhist rationale: as the interest accrues, so does the merit of the original donor.

Even though they are part of a slightly different argument, Walsh's remarks on Chinese monastic matters of economy during the Song Dynasty ring true with 
regard to the issues at hand, namely that "monks and nuns ... did not engage in socioeconomic practices in spite of their salvational or devotional dispositions; they engaged in such practices because of them." ${ }^{208}$ As far as I am aware, there was no linkage of usury with "sinfulness" among Tibetan Buddhists-or Indian Buddhists for that matter. This disproves the widespread notion that moneylenders were universally despised. In fact, Graeber, in his work that considers the morality of debt in time and place, points out that Buddhism "is one of the few of the great world religions that has never formally condemned usury." ${ }^{209}$ The proviso here is that the Sangha as the creditor is never faulted: the individual monk does get criticized for extracting interest on loans.

Naturally, there is no way of knowing how the debtors felt about their monastic creditors, but we do know that moneylending was generally not seen as morally reprehensible by ordinary Tibetans. Caple writes that, when researching the monastic economy in contemporary Rebkong in Amdo, she was told that local people who were relatively poor saw borrowing from the monastery and giving back interest as a form of giving to the monastery. ${ }^{210}$ Dagyab reports an instance in which Tibetans complied or even agreed with the economic policy of the monasteries: Ganden monastery, before 1959, both bought and sold grain. The monks in charge of this business had two sets of scales: one for buying and one for selling the wares. The local population was well aware that the scales had been tampered with so that the scales always tipped in favor of the monastery, but-at least according to oral history-people still preferred to do business with the monastery because of the merit involved. It was even perceived by some as a donation. ${ }^{211}$

It has been argued that the relatively good economic position of the monasteries before 1959 made it possible to help out the local population in difficult times with credit, and that in particular in areas where the infrastructure was poor, the monastery was an important giver of credit. ${ }^{212}$ However, as has been noted above, often only the wealthier people were eligible to do business with the monastery: the monastic corporation did not give out small loans to "the little people." The wealthier families pass on their loans to the poorer families, although they may also have been served with loans by the individual monks, thereby filling a niche in the market, albeit one that was not always legal, "Vinayically" speaking.

The alternative to seeing the monastery's commercial enterprises as usurious practices is to view them as a service, not that of a charitable institution, but that of, for example, a bank. Gernet, relying on various Vinayas, remarks that prior to the spread of Buddhism there were no lending banks, and that thus "Buddhist communities must be credited with their creation." ${ }^{213}$ Banks, in turn, are often recognized as catalysts of wider economic growth. The same parallel is drawn by Ekvall:

It is the Grwa tshang, or college, however, which, in the office and operations of the Spyi ba, or manager, corresponds most closely to the organization and function 
of the investment banking in other parts of the world. The analogy, though close, does not hold good in every respect. Although it operates like an investment banker, the monastery bank derives its capital from gifts and not from deposits on which it would have to pay interest or other financial outlay. The self-sacrifice of those who give, in terms of satisfaction derived, has not been ruinously or appallingly great. Nor have the sPyi Ba and others imposed altogether unreasonable interest rates or altogether stifled economic development. The sacrifice expressed in offering and the management of wealth together represent an economic contribution to the culture of Tibet. ${ }^{214}$

The real impact of the monasteries on the economy of pre-modern Tibet often gets ignored by scholars more concerned with issues of political or religious history. Alternatively, it is described as a burden on the ordinary people, a mode of exploitation of serfs, and an obstacle to economic development. The economic surplus is often portrayed as being solely used up for religious purposes. This understanding is countered when one views Tibetan monastic economic practices from a different perspective, namely as an economic "model" that was seen by Tibetans as a stable alternative to the hegemony of feuding aristocratic families ${ }^{215}$ and the decentralized government, which actively stimulated local-level governance. When placed in the historical context of Tibetan political history, the monastic economic model may have been the most viable option. Needless to say, this model has developed organically and gradually from the introduction of monastic Buddhism in Tibet onward and should not be seen as a model that has been deliberately created or adopted at a certain point in time.

To assert that the monastery performed the functions of a bank and that this institution as a main center of trade was seen as a better alternative is not the same as defending the economic practices in pre-modern Tibet (in particular from the point of view of the Western discourse on morality). However, it does contradict the notion that the reason a large part of the economic power was placed in the hands of the monasteries was due to the blind faith of the uneducated Tibetans, as certain apologists of the PRC's policies toward Tibet would have it. ${ }^{216}$ Tibetans, not unlike most people, were-and are-pragmatists at heart. However, as has been demonstrated time and again, pragmatism and religiosity are not mutually exclusive. This is not to say that the opposite is true either. While there are obvious parallels, a distinct difference between Buddhist (monastic) agents in financial issues and their medieval Christian counterparts is that among the latter the price of goods and money in general was continuously seen as an ethical issue: "they perceived justice rather than efficiency as an appropriate goal of economic policy." ${ }^{217}$ It has been argued that this Christian ideology concerning finance (which includes usury) halted or delayed the development of "a new economic system." ${ }^{218}$

The fact that Buddhist monks were committed to certain shared rules as well as to the rule of law, coupled with the fact that monasteries were perceived to be, as 
well as devised to be, stable institutions in what was often a largely unstable political setting, meant that the monastery's management of the local economy was, in the eyes of Tibetans, not undesirable. ${ }^{219}$

\section{CHALLENGING THE PARADOX OF MONASTIC PROPERTY}

While it has been argued that "profit taking was perfectly compatible with Buddhist philosophy," ${ }^{220}$ the combination of wealth accumulation and religious practice is more often than not seen as a paradox. Weber, for example, notes that: "The paradox of all rational asceticism, which in an identical manner has made monks in all ages stumble, is that rational asceticism itself has created the very wealth it rejected. Temples and monasteries have everywhere become the very loci of all rational economies." ${ }^{221}$ Reflecting on the contemporary economic practices of monasteries in Amdo, Caple views the idea that monasteries must improve and even compete "with the economic standards of secular life is in tension with the ideal of the 'simple monk"' This increasing material well-being of monks and their engagement with modern life is then seen in contemporary narratives as an element of moral decline. ${ }^{22}$ Here it is important to realize that, even though some monks maintain the attitude that hardship is good practice, ${ }^{223}$ historically, monks' living standards were on average higher than those of ordinary laypeople.

Whereas hardship among monks was occasionally espoused, large-scale destitution was never encouraged. Dungkar Lopzang Trinlé makes the link between poverty and discipline. He describes that in the time between the passing of the Fifth Dalai Lama up until 1958, certain monasteries that had autonomy, religious estates, workers, and a substantial (government) stipend were successful in maintaining and even increasing monk numbers, whereas the monasteries that relied only on wages and alms-begging saw their numbers drop no matter what they did. This, Dungkar Lopzang Trinlé asserts, resulted in the monks housed there not being able to sustain proper religious discipline. ${ }^{224}$

Despite perceived dichotomies, both in terms of ideology and practice, neither Tibetan monasteries nor Tibetan monks ever rejected wealth an sich. This is entirely in line with the Vinaya they adopted. The common overall principle is the nonattachment to wealth, which can be found in most Buddhist traditions. ${ }^{225}$ At first glance, there appears to be a conflict between rules on not having property beyond the stipulated items (on which, even in the Mülasarvāstivāda vinaya itself, the rules seem quite flexible) and the prohibition to refuse donations given to the Sangha (which would mean to deny the layman the accumulation of merit). ${ }^{226}$ However, it can be gleaned from the examples of the guidelines given earlier that concerns about not wasting the offerings given by the faithful and ensuring that they are used in the right way was prioritized over the simple lifestyle of individual monks. 
In many ways, the pivotal role of the Tibetan monastery in commercial enterprise was justified in terms of the Vinaya. Additionally, there are also various indications that ordinary people preferred doing business with monks and monasteries on account of the merit involved and the (financial) stability of the monastic institution. Walsh argues that, in medieval China, merit was the most powerful material religio-economic commodity monks produced and disseminated. ${ }^{227}$ In the context of pre-modern Tibet, it seems, stability vies with merit for being the most formidable monastic "product."

In this chapter a recurrent leitmotif has been the separation between the individual and the communal. The Sangha, as a corporation, has had almost no restrictions when it comes to accruing wealth, whereas the spending of that wealth is deemed more problematic. One could argue that Tibetan monasteries' economic policies were thus motivated by the freedoms and limitations, originally informed by the Indian Vinaya. At the same time, they were also heavily colored by the political situations, the Zeitgeist, and geographical limitations. It needs to be noted here that, for practical purposes, economic policy has been-at least nominallyseparated from social policy. Ultimately speaking, however, economic policy and social policy amount to the same thing. ${ }^{228}$ This may even be extended to religious policy. Gernet notes that there were two types of relationships between the laypeople and the monastery in medieval Buddhist China: one was religious and the other economic. He argues that people did not see these relationships as differing radically from one another. ${ }^{229}$ The next chapter deals with these social and religious policies executed by the monasteries-in particular those that concerned laypeople. 